\title{
Relationship between support for workers with illness and work functioning impairment in Japan during the COVID-19 pandemic
}

Yu Igarashi ${ }^{1}$, M.D., Ph.D., Seiichiro Tateishi ${ }^{2}$, M.D., Ph.D., Arisa Harada ${ }^{1}$, M.D., Ayako Hino ${ }^{3}$, M.D., Ph.D., Mayumi Tsuji ${ }^{4}$, M.D., Ph.D., Akira Ogami ${ }^{5}$, M.D., Ph.D., Koji Mori ${ }^{6}$, M.D., Ph.D., Ryutaro Matsugaki ${ }^{7}$, Ph.D., Yoshihisa Fujino ${ }^{8}$, M.D., M.P.H., Ph.D., for the CORoNaWork project

1 Department of Occupational Medicine, School of Medicine, University of

Occupational and Environmental Health, Japan

${ }^{2}$ Disaster Occupational Health Center, Institute of Industrial Ecological Sciences, University of Occupational and Environmental Health, Japan

${ }^{3}$ Department of Mental Health, Institute of Industrial Ecological Sciences, University of Occupational and Environmental Health, Japan

${ }^{4}$ Department of Environmental Health, School of Medicine, University of Occupational and Environmental Health, Japan 
${ }^{5}$ Department of Work Systems and Health, Institute of Industrial Ecological Sciences, University of Occupational and Environmental Health, Japan

${ }^{6}$ Department of Occupational Health Practice and Management, Institute of Industrial

Ecological Sciences, University of Occupational and Environmental Health, Japan

${ }^{7}$ Department of Preventive Medicine and Community Health, School of Medicine,

University of Occupational and Environmental Health, Japan

8 Department of Environmental Epidemiology, Institute of Industrial Ecological

Sciences, University of Occupational and Environmental Health, Japan

Correspondence to Seiichiro Tateishi, M.D., Ph.D.

Disaster Occupational Health Center, Institute of Industrial Ecological Sciences,

University of Occupational and Environmental Health, Japan

1-1, Iseigaoka, Yahatanishiku, Kitakyushu, 807-8555, Japan

Tel: +81-93-691-7323

Email: tateishi@med.uoeh-u.ac.jp 


\section{Sources of Funding}

This study was supported and partly funded by the research grant from the

University of Occupational and Environmental Health, Japan (no grant number);

Japanese Ministry of Health, Labour and Welfare (H30-josei-ippan-002,

H30-roudou-ippan-007, 19JA1004, 20JA1006, 210301-1, and 20HB1004); Anshin

Zaidan (no grant number), the Collabo-Health Study Group (no grant number), and

Hitachi Systems, Ltd. (no grant number) and scholarship donations from Chugai

Pharmaceutical Co., Ltd. (no grant number). The funder was not involved in the study

design, collection, analysis, interpretation of data, the writing of this article or the

decision to submit it for publication. All authors declare no other competing interests.

\section{Acknowledgements}

The current members of the CORoNaWork Project, in alphabetical order, are

as follows: Dr. Yoshihisa Fujino (present chairperson of the study group), Dr. Akira

Ogami, Dr. Arisa Harada, Dr. Ayako Hino, Dr. Hajime Ando, Dr. Hisashi Eguchi, Dr.

Kazunori Ikegami, Dr. Kei Tokutsu, Dr. Keiji Muramatsu, Dr. Koji Mori, Dr. Kosuke

Mafune, Dr. Kyoko Kitagawa, Dr. Masako Nagata, Dr. Mayumi Tsuji, Ms. Ning Liu,

Dr. Rie Tanaka, Dr. Ryutaro Matsugaki, Dr. Seiichiro Tateishi, Dr. Shinya Matsuda, Dr. 
medRxiv preprint doi: https://doi.org/10.1101/2021.09.23.21263920; this version posted January 2, 2022. The copyright holder for this preprint

(which was not certified by peer review) is the author/funder, who has granted medRxiv a license to display the preprint in perpetuity.

All rights reserved. No reuse allowed without permission.

Tomohiro Ishimaru, and Dr. Tomohisa Nagata. All members are affiliated with the

University of Occupational and Environmental Health, Japan.

\section{Conflict of interest}

None declared.

Ethics approval: This study was approved by the ethics committee of the University of

Occupational and Environmental Health, Japan (reference No.R2-079 and R3-006).

Running Title: Relationship between support for sick workers and WFun in the

CORoNaWork Project 
1 Abstract

2 Objective: This study examined the relationship between job accommodations for

3 workers with poor health and work functioning impairment during the COVID-19

4 pandemic.

5 Methods: An internet survey was conducted in December 2020. We included 24,429

6 subjects for analysis. One question was used to determine whether subjects needed job

$7 \quad$ accommodations from their company to continue working in their current health

8 condition. The odds ratios (ORs) of the necessity of job accommodations for sick

9 workers associated with work functioning impairment were estimated using multilevel

10 logistic regression analysis.

11 Results: The OR of work functioning impairment among sick workers not receiving

12 job accommodations was 5.75 (95\% confidence interval (CI) 5.34-6.20, p<0.001) and

13 those receiving job accommodations was 1.88 (95\% CI 1.69-2.08, $\mathrm{p}<0.001)$ compared

14 to healthy workers.

15 Conclusions: This study suggests that providing job accommodations to workers with

16 poor health may improve their work functioning impairment. 
18 Keywords: Work functioning impairment, Presenteeism, Job accommodations,

Introduction

health problem ${ }^{1}$. The development of new drugs and therapeutic devices, improved

33 being in poor health ${ }^{8}$. Poor health includes having either an acute or chronic illness, 
engage in presenteeism experience a variety of difficulties in their work. Specifically,

37 they have a higher risk of absenteeism and unemployment ${ }^{9-11}$, and lower work

38 productivity $^{11-13}$. Moreover, presenteeism reduces workers' quality of life $\mathrm{e}^{14}$. In addition,

39 prioritizing work may cause workers to miss opportunities for treatment, which may

40 lead to severe disease $\mathrm{e}^{15}$. To prevent the potentially detrimental effects of presenteeism

41 on employment and the course of workers' disease, it is important for companies to

42 accommodate workers who desire to continue working while in poor health.

There is a growing global movement for companies to provide job

51 ability to work. Around the world, this concept is known as "work accommodations,"

52 "reasonable accommodations," or "fit note"16-20. In Japan, it is called "Ryoritsu Shien,"

53 which means accommodating workers who desire to continue working despite being in 
54 poor health, with the Japanese government promoting "Ryoritsu Shien" to create a

55 society where people with poor health can also work. Accordingly, government

56 campaigns, guidelines, and a revision of medical fees have been implemented. Further,

57 some medical institutions have established new departments to promote the

58 accommodation of working people with poor health ${ }^{21-24}$. Accommodating the

employment of workers with poor health has a number of benefits, including reducing

60 loss of work productivity ${ }^{25}$, sickness absence ${ }^{26}$, the risk of job termination ${ }^{16,17,27}$ and

61 job stress ${ }^{16}$.

It is particularly important to provide job accommodations to workers with

63 poor health in the current COVID-19 pandemic, a period during which many have

66 In addition, workers with poor health suffer from psychological anxiety related to

67 being more susceptible to COVID-19 infection and having a high risk for disease

68 aggravation $^{30}$, which is thought to lead to reduced work performance among those with

69 poor health. Thus, job accommodations that make it more conducive for workers to

70 receive treatment and provide health guidance to workers with poor health during the 
medRxiv preprint doi: https://doi.org/10.1101/2021.09.23.21263920; this version posted January 2, 2022. The copyright holder for this preprint

(which was not certified by peer review) is the author/funder, who has granted medRxiv a license to display the preprint in perpetuity.

All rights reserved. No reuse allowed without permission.

71 COVID-19 pandemic are important for maintaining and improving workers' health

72 condition and work performance.

73

We hypothesized that job accommodations for workers with poor health

74 during the COVID-19 pandemic would improve or maintain work performance. Thus,

75 we examined the relationship between job accommodations provided by companies for

76 workers with poor health and a decline in work performance due to presenteeism

77 during the COVID-19 pandemic. We also stratified our analysis by job type, because

78 the relationship between workers with poor health and decreased work performance is

79 hypothesized to differ by the type of job being performed. Different job types can have

80 different characteristics, such as physical demands, loads from the physical

81 environment, and mental strains from overwork and interpersonal communication.

83 Methods

84 Study design and subjects

and Work) project was a cross-sectional internet monitoring survey conducted from

87 December 22 to 26,2020 , with the aim of examining the relationship between the 
pandemic $^{31}$. Data were collected through Cross Marketing Inc (Tokyo, Japan). From

bias caused by the large regional variation in COVID-19 infection rates across Japan. and improvements to the work environment are provided to workers by companies or 
medRxiv preprint doi: https://doi.org/10.1101/2021.09.23.21263920; this version posted January 2, 2022. The copyright holder for this preprint

(which was not certified by peer review) is the author/funder, who has granted medRxiv a license to display the preprint in perpetuity.

All rights reserved. No reuse allowed without permission.

107 accommodations from the company. A total of 24,429 individuals (12,184 males and

10812,245 females) were included in this analysis. This study was approved by the ethics

109 committee of the University of Occupational and Environmental Health, Japan

110 (reference No. R2-079). Informed consent was obtained using a form on the survey

111 website.

112

113 Assessment of job accommodations for workers with poor health

114 A single-item question was used to determine workers' need for job

115 accommodations: "Do you need any job accommodations from your company to

116 continue working in your current health condition?" The participants responded by

117 choosing from "Not necessary", "Yes, but I am not receiving any accommodations",

118 and "Yes, I am receiving accommodations". We classified subjects who answered

119 "Not necessary" as healthy workers, "Yes, but I am not receiving any accommodations"

120 as sick workers not receiving job accommodations from their company, and "Yes, I am

121 receiving accommodations" as sick workers receiving job accommodations from their

122 company.

123

124 Assessment of work functioning impairment 
127 developed using the Rasch model ${ }^{32}$. It consists of seven questions and the total score

impairment due to health problems. WFun has been confirmed for hypothesis testing, 
143 job accommodations is unclear, we think that the provision of job accommodations by

144 companies is related to socioeconomic status; this is another reason for the inclusion of

145 the above factors as confounders in this study.

$147 \quad$ Statistical analysis and mainly manual labor).

\section{Results}



receiving job accommodations from their company, and 9.5\% $(\mathrm{n}=2,310)$ were sick workers not receiving job accommodations from their company. The mean age and proportion of current smokers were lower among sick workers receiving job accommodations than sick workers not receiving job accommodations from their company. In contrast, household income, educational background, and the number of employees at the workplace tended to be higher among sick workers receiving job accommodations than sick workers not receiving job accommodations from their company. The proportion of married employees was higher among healthy workers than others. among sick workers not receiving job accommodations and 1.88 times higher among sick workers receiving job accommodations from their company than healthy workers. 
179 impairment were 5.59 times higher among sick workers not receiving job

180 accommodations and 1.85 times higher among sick workers receiving job

181 accommodations from their company than healthy workers.

182 We also examined the relationship after stratifying by job type: mainly desk

183 work, mainly interpersonal communication, mainly manual labor. Among subjects

engaged mainly in desk work, the odds of mild to severe work functioning impairment

were 6.83 times higher among sick workers not receiving job accommodations and

1.95 times higher among sick workers receiving job accommodations from their

company than healthy workers. Likewise, among subjects engaged mainly in

interpersonal communication, the odds of mild to severe work functioning impairment

were 4.81 times higher among sick workers not receiving job accommodations and

company than healthy workers. Similarly, among subjects engaged mainly in manual

195 Multivariate analysis showed similar trends in the adjusted odds of mild to severe work

196 functioning impairment to those observed in the unadjusted models. 
198 Discussion

213 have been reported to experience work disability and lower work productivity ${ }^{11-13}$.

214 There are a variety of reasons why workers with poor health have reduced work ability. 
medRxiv preprint doi: https://doi.org/10.1101/2021.09.23.21263920; this version posted January 2, 2022. The copyright holder for this preprint

(which was not certified by peer review) is the author/funder, who has granted medRxiv a license to display the preprint in perpetuity.

All rights reserved. No reuse allowed without permission.

215 First, the nature of their symptoms or illness can reduce workers' ability to perform

216 their job or certain tasks. For example, pain or musculoskeletal diseases, which are

217 typical causes of presenteeism, lead to decreased physical tolerance and hinder

218 performance in tasks such as handling heavy objects. In addition, sleep disorders and

219 mental health problems, which are a major cause of presenteeism, impair concentration

220 and cognitive function ${ }^{39}$. Some conditions require workers to restrict certain tasks,

221 such as shift work, business trips, and work at heights, to ensure safety and to avoid

222 worsening their condition. Second, hospitalization and hospital visits for treatment may

223 reduce working hours and interrupt work schedules. Individuals who work while

224 experiencing work-related disability due to presenteeism have an increased risk of

225 future days off work, job loss, and exclusion from the labor market ${ }^{9-11}$. Providing

226 appropriate job accommodations to workers, such as changing the contents of their

227 work and adjusting their working hours, is expected to decrease the loss in work

228 performance due to presenteeism and to reduce the risk of lost work days and

229 unemployment.

230 Job accommodations can reduce work functioning impairment among

231 workers with poor health. In this study, we found that the odds of mild to severe work

232 functioning impairment was approximately three times higher among workers who 
were not receiving job accommodations than those who were receiving job

performing their duties and continuing to work. Providing job accommodations for

a good health climate, or the perception by employees that the team to which they

244 productivity loss due to presenteeism ${ }^{40-41}$. In addition, a good health climate is 
medRxiv preprint doi: https://doi.org/10.1101/2021.09.23.21263920; this version posted January 2, 2022. The copyright holder for this preprint

(which was not certified by peer review) is the author/funder, who has granted medRxiv a license to display the preprint in perpetuity.

All rights reserved. No reuse allowed without permission.

251 interpersonal communication, and primarily physical labor. Different job types have

252 different degrees of psychological and physical demands. Workers with back pain who

253 engage in physical work naturally require different accommodations to those

254 undergoing anti-cancer drug treatment who work at a desk. While we did not identify

255 the details of the accommodations provided, our results nevertheless suggest that

256 providing accommodations for workers based on their job type and health condition

257 that are in line with their needs is useful for slowing or halting the decline in work

258 functioning impairment across all job types. While job accommodations are

259 increasingly being recommended for workers with poor health, there remains no

260 unified view on the best types of accommodations to offer workers with certain

261 illnesses and performing certain jobs. Job accommodations are currently being chosen

262 through collaboration among workers, employers, attending physicians, and industrial

263 physicians. In the future, studies may identify concrete recommendations of the most

264 effective type of accommodations to provide workers according to job type.

265 This study had some limitations. First, because we conducted a survey of

266 Internet monitors, a degree of selection bias was unavoidable. To minimize this, we

267 selected subjects based on their region, occupation, and prefecture according to the

268 cumulative infection rate from January to December 2020. Second, given the 
medRxiv preprint doi: https://doi.org/10.1101/2021.09.23.21263920; this version posted January 2, 2022. The copyright holder for this preprint (which was not certified by peer review) is the author/funder, who has granted medRxiv a license to display the preprint in perpetuity.

All rights reserved. No reuse allowed without permission.

cross-sectional design, we could not determine the causal relationship between job accommodations provided by companies for workers with poor health and work

functioning impairment. Workers with mild work functioning impairment who are able to work may receive job accommodations more readily. Third, we did not identify workers' symptoms or disease in our study. The effect of job accommodations on the improvement in work functioning impairment may depend on the type and degree of poor health or symptoms exhibited by workers, combined with their job and tasks.

Fourth, we used only one question to assess whether or not workers were receiving job accommodations from their company, which may not be sufficiently valid. In conclusion, this study showed that there is a relationship between job accommodations provided by companies for workers with poor health and work functioning impairment in a large population of workers across Japan. Workers with poor health who were receiving job accommodations were less likely to have work functioning impairment than those who reported not receiving job accommodations.

These results suggest that providing accommodations to workers with poor health may improve their work functioning impairment.

References 

burden of cancer to individuals and society. Work. 2013;46:455-72. Scand. 2020;141(1):56-64. work for people with coronary heart disease. Cochrane Database Syst Rev. 2019;2019(3):CD010748.

5. Palmer KT, Harris C, Linaker C, et al. Effectiveness of community- and absence and job loss - a systematic review. Rheumatology (Oxford). 2012;51(2):230-242. 
medRxiv preprint doi: https://doi.org/10.1101/2021.09.23.21263920; this version posted January 2, 2022. The copyright holder for this preprint (which was not certified by peer review) is the author/funder, who has granted medRxiv a license to display the preprint in perpetuity.

All rights reserved. No reuse allowed without permission.

6. Prins R. Sickness absence and disability: an international perspective. In: Loisel

P, Anema JR, eds. Handbook of Work Disability: Prevention and Management.

Springer; 2013:3-14.

7. EUROSTAT. hlth_dlm040—population by type of disability, sex, age and labour status [Table]. EUROSTAT;

2011.https://appsso.eurostat.ec.europa.eu/nui/submitViewTableAction.do

Accessed August 25, 2021.

8. Brooks A, Hagen SE, Sathyanarayanan S, Schultz AB, Edington DW. Presenteeism: critical issues. J Occup Environ Med. 2010;52(11):1055-1067.

9. Fujino Y, Shazuki S, Izumi H, et al. Prospective cohort study of work functioning impairment and subsequent absenteeism among Japanese workers. J Occup Environ Med. 2016;58(7):e264-267.

10. Hansen CD, Andersen JH. Sick at work--a risk factor for long-term sickness absence at a later date? J Epidemiol Community Health. 2009;63(5):397-402. preventable burden of productivity loss due to suboptimal asthma control: a population-based study. Chest. 2014;145(4):787-793. 
12. Dellve L, Hadzibajramovic E, Ahlborg G. Work attendance among healthcare workers: prevalence, incentives, and long-term consequences for health and performance. J Adv Nurs. 2011;67(9):1918-1929.

13. Merchant JA, Kelly KM, Burmeister LF, et al. Employment status matters: a statewide survey of quality-of-life, prevention behaviors, and absenteeism and presenteeism. J Occup Environ Med. 2014;56(7):686-698.

14. Schmitt JM, Ford DE. Work limitations and productivity loss are associated with health-related quality of life but not with clinical severity in patients with psoriasis. Dermatology. 2006;213(2):102-110.

15. Kinman G. Sickness presenteeism at work: prevalence, costs and management. Br Med Bull. 2019;129(1):69-78.

16. Zafar N, Rotenberg M, Rudnick A. A systematic review of work accommodations for people with mental disorders. Work. 2019;64(3):461-475.

17. Chow CM, Cichocki B, Croft B. The impact of job accommodations on employment outcomes among individuals with psychiatric disabilities. Psychiatr Serv. 2014;65(9):1126-1132.

18. Thornhill S, Williams N. Completion of the statement of fitness for work: concise guidance. Clin Med (Lond). 2012;12(1):63-66. 
medRxiv preprint doi: https://doi.org/10.1101/2021.09.23.21263920; this version posted January 2, 2022. The copyright holder for this preprint (which was not certified by peer review) is the author/funder, who has granted medRxiv a license to display the preprint in perpetuity.

All rights reserved. No reuse allowed without permission.

19. Dorrington S, Roberts E, Mykletun A, Hatch S, Madan I, Hotopf M. Systematic review of fit note use for workers in the UK. Occup Environ Med. 2018;75(7):530-539.

20. Paulides E, Gearry RB, de Boer NKH, Mulder CJJ, Bernstein CN, McCombie AM. Accommodations and adaptations to overcome workplace disability in inflammatory bowel disease patients: a systematic review. Inflamm Intest Dis. 2019;3(3):138-144.

21. Ministry of Health, Labour and Welfare. Vital Statistics 2015. (In Japanese). https://www.mhlw.go.jp/toukei/saikin/hw/jinkou/kakutei15/ Accessed September 1, 2021.

22. The Japan Institute for Labour Policy and Training. Survey on Balancing Work and Illness Treatment (Web-based Patient Survey)2018. (In Japanese)_ https://www.jil.go.jp/institute/research/2018/180.html Accessed September 1, 2021.

\section{Ministry of Health, Labour and Welfare. Guideline for Support of Balancing} Medical Treatment and Occupational Life in the Workplace (in Japanese). https://www.mhlw.go.jp/stf/seisakunitsuite/bunya/0000115267.html Accessed September 1, 2021. 
24. Minohara R et al. Qualitative analysis of provided information and advice from occupational physicians to attending clinical physicians in supporting an employee $\square \mathrm{s}$ work $\square$ treatment balance. Sangyo Eiseigaku Zasshi. 2021;63(1):6-20. (In Japanese)

25. Okubo K, Gotoh M, Shimada K, Ritsu M, Okuda M, Crawford B.

Fexofenadine improves the quality of life and work productivity in Japanese patients with seasonal allergic rhinitis during the peak cedar pollinosis season. Int Arch Allergy Immunol. 2005;136(2):148-154.

26. dos Santos K, Kupek E, Cunha JCCB, Blank VLG. Sickness-absenteeism, job demand-control model, and social support: a case-control study nested in a cohort of hospital workers, Santa Catarina, Brazil. Rev Bras Epidemiol. 2011;14(4):609-619.

27. Spelten ER, Sprangers MAG, Verbeek JHAM. Factors reported to influence the return to work of cancer survivors: a literature review. Psychooncology. 2002;11(2):124-131.

28. Czeisler MÉ, Marynak K, Clarke KEN, et al. Delay or Avoidance of Medical Care Because of COVID-19-Related Concerns - United States, June 2020. MMWR Morb Mortal Wkly Rep. 2020;69(36):1250-1257. 
29. Chudasama YV, Gillies CL, Zaccardi F, et al. Impact of COVID-19 on routine care for chronic diseases: A global survey of views from healthcare professionals. Diabetes Metab Syndr. 2020;14(5):965-967.

30. Erol MK, Kayıkçıoğlu M, Kılıçkap M, et al. Treatment delays and in-hospital outcomes in acute myocardial infarction during the COVID-19 pandemic: A nationwide study. Anatol J Cardiol. 2020;24(5):334-342.

31. Fujino Y, Ishimaru T, Eguchi H, et al. Protocol for a nationwide internet-based health survey of workers during the covid-19 pandemic in 2020. J UOEH. 2021;43(2):217-225.

32. Fujino Y, Uehara M, Izumi H, et al. Development and validity of a work functioning impairment scale based on the Rasch model among Japanese workers. J Occup Health. 2015;57(6):521-531.

33. Nagata T, Fujino Y, Saito K, et al. Diagnostic accuracy of the work functioning impairment scale (Wfun): a method to detect workers who have health problems affecting their work and to evaluate fitness for work. J Occup Environ Med. 2017;59(6):557-562.

34. Susser P, Ziebarth NR. Profiling the u. S. Sick leave landscape: presenteeism among females. Health Serv Res. 2016;51(6):2305-2317. 
medRxiv preprint doi: https://doi.org/10.1101/2021.09.23.21263920; this version posted January 2, 2022. The copyright holder for this preprint (which was not certified by peer review) is the author/funder, who has granted medRxiv a license to display the preprint in perpetuity.

All rights reserved. No reuse allowed without permission.

35. Wee LH, Yeap LLL, Chan CMH, et al. Anteceding factors predicting absenteeism and presenteeism in urban area in Malaysia. BMC Public Health. 2019;19(Suppl 4):540.

36. Li W, Moriyama M, Cui Y, Kazawa K, Nakaya T, Susanto T. Presenteeism among Chinese workers in Japan and its relationship with mental health and health-promoting lifestyles. Ind Health. 2020;58(1):35-45.

37. Mekonnen TH, Tefera MA, Melsew YA. Sick at work: prevalence and determinants among healthcare workers, western Ethiopia: an institution based cross-sectional study. Ann Occup Environ Med. 2018;30:2.

38. R Core Team (2020). R: A language and environment for statistical computing. R Foundation for Statistical Computing, Vienna, Austria. URL_ https://www.R-project.org/.

39. Swanson LM, Arnedt JT, Rosekind MR, Belenky G, Balkin TJ, Drake C. Sleep disorders and work performance: findings from the 2008 National Sleep Foundation Sleep in America poll. J Sleep Res. 2011;20(3):487-494.

40. Saijo Y, Yoshioka E, Nakagi Y, Kawanishi Y, Hanley SJB, Yoshida T. Social support and its interrelationships with demand-control model factors on 
medRxiv preprint doi: https://doi.org/10.1101/2021.09.23.21263920; this version posted January 2, 2022. The copyright holder for this preprint (which was not certified by peer review) is the author/funder, who has granted medRxiv a license to display the preprint in perpetuity.

All rights reserved. No reuse allowed without permission.

$410 \quad$ presenteeism and absenteeism in Japanese civil servants. Int Arch Occup

411 Environ Health. 2017;90(6):539-553.

412

413

41. Schmid JA, Jarczok MN, Sonntag D, Herr RM, Fischer JE, Schmidt B.

Associations between supportive leadership behavior and the costs of

absenteeism and presenteeism: an epidemiological and economic approach. $J$

Occup Environ Med. 2017;59(2):141-147.

42. Zanon REB, Dalmolin G de L, Magnago TSB de S, Andolhe R, Carvalho

REFL de. Presenteeism and safety culture: evaluation of health workers in a

teaching hospital. Rev Bras Enferm. 2021;74(1):e20190463.

43. Schulz H, Zacher H, Lippke S. The importance of team health climate for health-related outcomes of white-collar workers. Front Psychol. 2017;8:74.

44. Liu B, Lu Q, Zhao Y, Zhan J. Can the psychosocial safety climate reduce ill-health presenteeism? Evidence from Chinese healthcare staff under a dual information processing path lens. Int J Environ Res Public Health. 2020;17(8):E2969. 
Table1. Characteristic of the subjects

\begin{tabular}{|c|c|c|c|c|c|c|}
\hline \multirow[b]{2}{*}{ Characteristic } & \multicolumn{2}{|c|}{$\begin{array}{l}\text { Healthy workers } \\
\qquad(\mathrm{n}=18,120)\end{array}$} & \multicolumn{2}{|c|}{$\begin{array}{l}\text { Sick workers not } \\
\text { receiving job } \\
\text { accommodations } \\
\text { from their } \\
\text { company } \\
(\mathrm{n}=3,999)\end{array}$} & \multicolumn{2}{|c|}{$\begin{array}{c}\text { Sick workers } \\
\text { receiving job } \\
\text { accommodations } \\
\text { from their } \\
\text { company } \\
(\mathrm{n}=2,310)\end{array}$} \\
\hline & $\mathrm{n}$ & $\%$ & $\mathrm{n}$ & $\%$ & $\mathrm{n}$ & $\%$ \\
\hline Age, mean (SD) & $\begin{array}{c}46.8 \\
(10.6)^{*}\end{array}$ & & $\begin{array}{c}45.9 \\
(10.2)^{*}\end{array}$ & & $\begin{array}{c}44.9 \\
(10.9)^{*}\end{array}$ & \\
\hline Sex, men & 9,117 & 50 & 1,985 & 50 & 1,082 & 47 \\
\hline \multicolumn{7}{|l|}{ Household income } \\
\hline 200-299million yen & 2,256 & 12 & 770 & 19 & 340 & 15 \\
\hline 300-499million yen & 4,216 & 23 & 1,090 & 27 & 549 & 24 \\
\hline 500-699million yen & 3,994 & 22 & 851 & 21 & 484 & 21 \\
\hline 700-899million yen & 3,309 & 18 & 593 & 15 & 437 & 19 \\
\hline 900 million yen or more & 4,345 & 24 & 695 & 17 & 500 & 22 \\
\hline \multicolumn{7}{|l|}{ Education status } \\
\hline Junior high school & 211 & 1 & 71 & 2 & 26 & 1 \\
\hline High school & 4,647 & 26 & 1,061 & 27 & 545 & 24 \\
\hline $\begin{array}{l}\text { Vocational } \\
\text { school/college, Universtiy, } \\
\text { Graduate school }\end{array}$ & 13,262 & 73 & 2,867 & 72 & 1,739 & 75 \\
\hline Cuurent smoker & 4,504 & 25 & 1,135 & 28 & 517 & 22 \\
\hline \multicolumn{7}{|l|}{$\begin{array}{l}\text { Number of employees at the } \\
\text { workplace }\end{array}$} \\
\hline$<10$ & 2,801 & 15 & 546 & 14 & 312 & 14 \\
\hline$<100$ & 5,063 & 28 & 1,179 & 29 & 621 & 27 \\
\hline$<1000$ & 5,246 & 29 & 1,246 & 31 & 648 & 28 \\
\hline$>1000$ & 5,010 & 28 & 1,028 & 26 & 729 & 32 \\
\hline \multicolumn{7}{|l|}{ Marriage status, married } \\
\hline & 10,379 & 57 & 2,034 & 51 & 1,238 & 54 \\
\hline
\end{tabular}


medRxiv preprint doi: https://doi.org/10.1101/2021.09.23.21263920; this version posted January 2, 2022. The copyright holder for this preprint (which was not certified by peer review) is the author/funder, who has granted medRxiv a license to display the preprint in perpetuity.

All rights reserved. No reuse allowed without permission. 
Table 2. Odds ratios and adjusted odds ratios for multivariate model of mild to severe work function impairment

\begin{tabular}{|c|c|c|c|c|c|c|c|c|c|}
\hline \multirow{2}{*}{$\begin{array}{l}\text { Mild to severe work function impairment (WFun>=21) } \\
\text { All subjects }\end{array}$} & \multirow[b]{2}{*}{$\mathrm{n}$} & \multicolumn{4}{|c|}{ Model 1} & \multicolumn{4}{|c|}{ Model 2} \\
\hline & & OR & $95 \%$ & $\mathrm{CI}$ & $\mathrm{P}$ value & OR & $95 \%$ & $\mathrm{CI}$ & $P$ value \\
\hline & & & & & & & & & \\
\hline Healthy workers & 18,120 & 1.00 & & & & 1.00 & & & \\
\hline $\begin{array}{l}\text { Sick workers not receiving job accommodations from } \\
\text { their company }\end{array}$ & 3,999 & 5.75 & 5.34 & 6.20 & $<0.001$ & 5.59 & 5.19 & 6.03 & $<0.001$ \\
\hline $\begin{array}{l}\text { Sick workers receiving job accommodations from } \\
\text { their company }\end{array}$ & 2,310 & 1.88 & 1.69 & 2.08 & $<0.001$ & 1.85 & 1.67 & 2.05 & $<0.001$ \\
\hline Mainly desk work & 12,486 & & & & & & & & \\
\hline Healthy workers & 9,496 & 1.00 & & & & 1.00 & & & \\
\hline $\begin{array}{l}\text { Sick workers not receiving job accommodations from } \\
\text { their company }\end{array}$ & 1,831 & 6.83 & 6.13 & 7.61 & $<0.001$ & 6.60 & 5.92 & 7.36 & $<0.001$ \\
\hline $\begin{array}{l}\text { Sick workers receiving job accommodations from } \\
\text { their company }\end{array}$ & 1,159 & 1.95 & 1.69 & 2.25 & $<0.001$ & 1.92 & 1.66 & 2.22 & $<0.001$ \\
\hline Mainly interpersonal communication & 5,884 & & & & & & & & \\
\hline Healthy workers & 4,327 & 1.00 & & & & 1.00 & & & \\
\hline $\begin{array}{l}\text { Sick workers not receiving job accommodations from } \\
\text { their company }\end{array}$ & 1,022 & 4.81 & 4.15 & 5.59 & $<0.001$ & 4.70 & 4.05 & 5.46 & $<0.001$ \\
\hline Sick workers receiving job accommodations from & 535 & 1.93 & 1.56 & 2.38 & $<0.001$ & 1.94 & 1.56 & 2.38 & $<0.001$ \\
\hline
\end{tabular}


Mainly manual labor

Healthy workers

Sick workers not receiving job accommodations from their company

Sick workers receiving job accommodations from their company

Model 1: Adjusted for age, sex

Model 2: Further adjusted for household income, educational status, number of employees at the workplace and marriage status

6,059
4,297

1,146 1.00

1.00

616

5.18 4.48 5.99

$<0.001$
$5.07 \quad 4.38 \quad 5.86$

$<0.001$

616 1.68 1.37

2.06

$<0.001$ $\begin{array}{llll}1.66 & 1.35 & 2.03 & <0.001\end{array}$

$<0.001$

